\title{
Corporate Governance Codes and Intellectual Capital: Evaluating the Performance Impacts among Government-Linked Companies in Malaysia and Singapore - A Panel Data Analysis
}

\author{
Yen Wen Chang ${ }^{1, *}, N g$ Ching Yat David ${ }^{1}$, Suet Cheng Low ${ }^{1}$ and Peck Ling Tee ${ }^{1}$ \\ ${ }^{1}$ Department of Accounting, Faculty of Accountancy and Management, Universiti Tunku Abdul \\ Rahman, Malaysia
}

\begin{abstract}
The objective of this study was to examine and compare the effects of corporate governance (CG) and intellectual capital (IC) between Malaysia Government-Linked Companies' (M-GLCs) and Singapore Government-Linked Companies' (S-GLCs) firm performance (FP). Panel data analysis was employed to analyse the impact of CG's variables and IC's variables on FP. FP was measured by Return on Total Assets (ROA), Tobin's Q and Earnings Per Share (EPS). Data was gathered from the website of Bursa Malaysia and the Stock Exchange of Singapore from 2005 to 2018. The sample size of this research was 60 GLCs which comprised of $34 \mathrm{M}-$ GLCs and 26 S-GLCs. There were a total 840 firm year observations. Results indicated that CGs of S-GLCs have greater impact on FP when compared to M-GLCs while the findings of the IC of M-GLCs have greater impact on FP compared to S-GLCs. This research was helpful in offering further insights of CG practices and IC efficiency to the Government, Board of Directors, policy makers, shareholders and stakeholders.
\end{abstract}

\section{Introduction}

Government-linked companies (GLCs) play a widespread and pervasive role in the economy of Malaysia and Singapore. Malaysia was ranked as fifth-highest in the world in terms of countries that have the highest GLCs existence among its largest firms (Kowalski, Buge, Sztajerowska, \& Egeland, 2013). The formation of Singapore GLCs in the late 1960s was to promote industrialization and development in strategic industries of the economy (Chen, 2016). According to Vitolla, Raimo and Rubino (2020), the Board composition must be responsive to the essential tasks that were assigned to them, for instance, avoiding conflict of interest with shareholders, supervising and monitoring the company and providing suggestions to top management which will lead to enhance a firm's FP. Boateng, Manu and Adesi (2019) found that purposes of CG were to reinforce the companies' structure for transparency, efficient performance and trust among all stakeholders of the company. Ibrahimy and Raman (2019) mentioned that the physical assets, such as, land, inventories, buildings and machinery was not only the indicator to determine the growth of the world,

${ }^{*}$ Corresponding author: cherlychang0118@1utar.my 
nation, business or company; it can also be determined by the growth by IC, it can be transferred into profit but is not reflected on the financial statements.

\subsection{Problem Statement}

According to Soei, Setiawan and Fitriani (2019), good CG became a critical issue from the Asian Financial Crisis in 1997. However, most research examined the effects of CG on Public-Listed Companies (PLCs) FP but not on M-GLCs (Mohamad, Pantamee, \& Keong, 2020; Tan \& Patricia, 2020) and S-GLCs (Chen, 2019; Duppati, Rao, Matlani, \& Scrimgeour, 2019). Even though the number of research studies on CG topic had recently increased, there was still an absence of research that examined and compared the effects of CG between MGLCs and S-GLCs FP. Besides, the effect of IC on FP was rarely studied. For instance, Ibrahimy and Raman (2019) and Kweh, Ting, Hanh, and Zhang (2019), explored the influence of IC on FP among Malaysia PLCs but not GLCs. Research conducted on the influence of IC on FP among Singapore PLCs was limited, such as Tan, Plowman, \& Hancock (2007) while no research was conducted on the effects of IC on FP among S-GLCs. The effects of CG and IC on FP was being conducted in most of the existing empirical literature, but there were inconsistent outcome, for instance, Haq, Zhao and Rehman (2020), Ullah and Kamal (2020) and Shachi, Jophi and Prakash (2020) provided the mixed results. Hence, this research was carried to further study and examine the effects of CG and IC between M-GLCs and S-GLCs FP in order to narrow up the gap of outcomes.

\section{Literature Review and Hypothesis Development}

To analyze CG and IC, a few of the theoretical frameworks were introduced. Each of these frameworks come from different disciplines through numerous studies that were conducted.

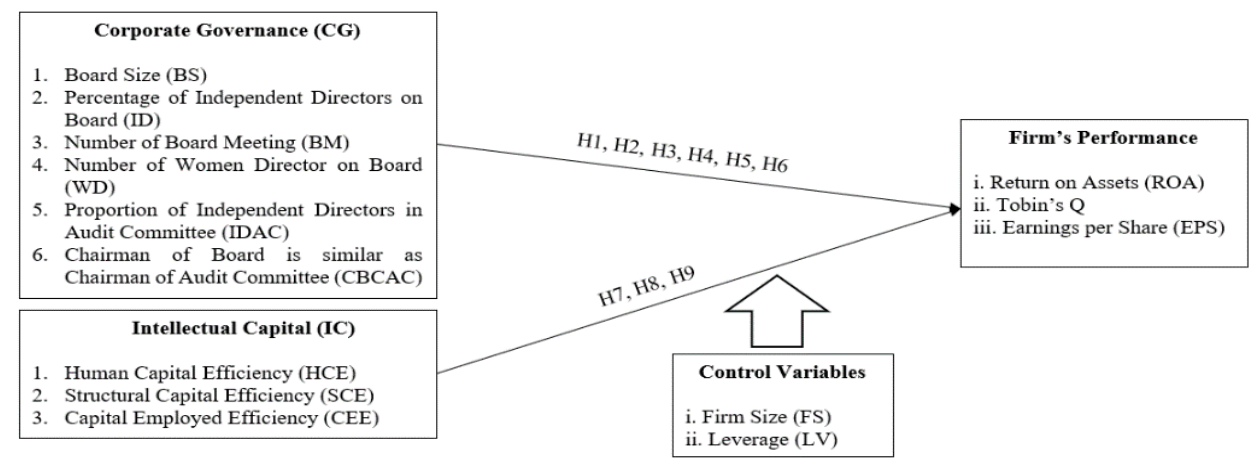

Fig. 1. Proposed Theoretical Framework.

\subsection{Relationship between Board Size (BS) and Firm Performance}

The optimum BS was able to oversee the operation and management of the firm successfully and enhance the profit of shareholders (Kao, Hodgkinson, \& Jaafar, 2019). According to Puni and Anlesinya (2020), agency theory recommended that the appropriate BS was able to improve communication and harmonisation on the Board. They argued that a larger BS might increase agency costs because the Boards have the probability of losing direction and face communication challenges. Most prior research found that a larger BS was less effective in improving $\mathrm{FP}$ as it required high monitoring costs, which consistent with agency theory 
(Younas, Klein, \& Trabert, 2019). According to Syajarul and Shifa (2019), the high levels of conflict and low levels of group cohesion might happen in the large BS.

$H_{1 A}: B S$ of $M-G L C s$ have a greater impact on ROA compared to that of S-GLCS.

$H_{1 B}$ : BS of M-GLCs have a greater impact on Tobin's Q compared to that of S-GLCs.

$H_{I C}: B S$ of $M-G L C s$ have a greater impact on EPS compared to that of S-GLCs.

\subsection{Relationship between Percentage of Independent Directors on Board (ID) and Firm Performance}

According to Dionne, Chun and Triki (2019), IDs or external directors would not collude with the chairman of the Board or CEO to threaten shareholders' interest because they play their supervisory role effectively. Therefore, a Board should involve independent directors to keep safe the interest of shareholders and improve FP (Masulins \& Zhang, 2019). In the study of Merendino and Melville (2019), they stated that IDs has a significant positive relation with FP under the agency theory. This is because a higher number of IDs may have more active monitoring roles and limit managerial opportunism. On the contrary, Kweh, Ahmad and Ting (2019) concluded that the correlation between IDs and FP was negative as IDs were external directors, they did not possess the power to impact the decisions and actions made by the CEO in order to secured shareholders' wealth.

$H_{2 A}$ : IDs of $M-G L C s$ have a greater impact on ROA compared to that of S-GLCs.

$H_{2 B}$ : IDs of M-GLCs have a greater impact on Tobin's $Q$ compared to that of $S$-GLCs.

$H_{2 C}$ : IDs of $M-G L C s$ have a greater impact on EPS compared to that of S-GLCs.

\subsection{Relationship between Number of Board Meetings (BM) and Firm Performance}

According to Ji, Talavera and Yin (2020), BM was the most easily practiced Board activity, and it was mandatory in public companies in order to enhance the Board effectiveness. In stewardship theory, the steward will feel autonomously secure and maximise the interests of their principals in term of FP (Obermann, Velte, \& Gerwanski, 2020). The BODs and managers represented the steward, while the principal referred to the shareholders or the owners (Wijethilake \& Ekanayake, 2019). BM had a significant impact on FP because of strategic guidance about investment opportunities (Wang, Abbasi, \& Babajide, 2020). According to Arulvel and Pratheepkanth (2019), conflict of interest and the agency cost can be effectively diminished by the decisions made during BM.

$H_{3 A}: B M$ of $M$-GLCs have a greater impact on ROA compared to that of S-GLCs.

$H_{3 B}$ : BM of M-GLCs have a greater impact on Tobin's $Q$ compared to that of $S$-GLCs.

$H_{3 C}: B M$ of $M-G L C s$ have a greater impact on EPS compared to that of S-GLCs.

\subsection{Relationship between Number of Women Directors in Board (WD) and Firm Performance}

Gender diversity can be enforced with the presence of WD on the Board (Ying \& Rayappan, 2020). The exclusive supervision style and comprehensiveness of WD could form the dynamics of the Board and enhance the FP (Larkin, 2020). WD would encourage the participative environment with changed and improved the communications and negotiations style on Board (Kanojia \& Khanna, 2019). As aligned with agency theory, WD was able to improve FP by improving Board independence and monitoring functions (Wahid, 2019). On the other hand, Einarsdottir, Rafnsdottir and Sigrun (2020) stated that Board homogeneity were not link to gender issues. According to Rekha (2019), WD was unable to improve the FP because the Board diversity may give rise to conflicts and disagreements among the BODs. 
$H_{4 A}$ : WD of M-GLCs have a greater impact on ROA compared to that of S-GLCs.

$H_{4 B}$ : WD of M-GLCs have a greater impact on Tobin's $Q$ compared to that of S-GLCs.

$H_{4 C}: W D$ of $M-G L C s$ have a greater impact on EPS compared to that of S-GLCs.

\subsection{Relationship between Proportion of Independent Directors in the Audit Committee (IDAC) and Firm Performance}

Norziaton and Hafizah (2019) stated that the main requirement of a competent audit committee where it should be independent from the management of the company. Farooque, Buachoom, and Sun (2020) concluded that the firm should have high IDAC in order to secure the rights and benefits of stakeholders and thus enhance the FP. This viewpoint was similar to the stakeholder theory, which argued that the success of the firm primarily relies on the informational and interests needs of its major stakeholders, for instance, the government, employees and customers. In additions, the non-executive directors would possess the capability to eliminate the issues of financial statement manipulation (Astami \& Rusmin, 2020). In short, FP and shareholder's wealth can be improved by high IDAC, because there have better supervising functions of the Board.

$H_{5 A}$ : IDAC of M-GLCs have a greater impact on ROA compared to that of S-GLCs.

$H_{5 B}$ : IDAC of M-GLCs have a greater impact on Tobin's $Q$ compared to that of S-GLCs.

$H_{5 C}$ : IDAC of M-GLCs have a greater impact on EPS compared to that of S-GLCs.

\subsection{Relationship between Chairman of Board is similar as Chairman of the Audit Committee (CBCAC) and Firm Performance}

According to the Practice 8.1 of MCCG 2017, it stated that the chairman of the Board could not hold the position as the chairman of the audit committee. The chairman of the audit committee not only must be an independent director, but he or she also should not hold the position of chairman of the Board. There is a conflict of interests in the findings and recommendations of the audit committee if the person holds these two positions at the same time. CBCAC may cause the issue of concentration of the control power that is held by a single director. Additionally, according to the Standard 12.4 of Bank Negara Malaysia's Policy Document on Corporate Governance, it suggested that it is necessary for the financial institution to support a distinction of CBCAC. There is a need to split these two positions because it would allow the chairman of the audit committee to assign enough time to deal with the events in the audit committee. CBCAC would cause a particular director to have overloaded responsibilities and duties, leading to diminished performance of a particular director.

$H_{6 A}: C B C A C$ of $M-G L C s$ have a greater impact on ROA compared to that of $S$-GLCs.

$H_{6 B}: C B C A C$ of $M-G L C s$ have a greater impact on Tobin's $Q$ compared to that of S-GLCs. $H_{6 C}: C B C A C$ of $M-G L C s$ have a greater impact on EPS compared to that of $S$-GLCs.

\subsection{Relationship between Human Capital Efficiency (HCE) and Firm Performance}

Ting, Ren and Chen (2020) stated that the experiences, skills and knowledge that are held by employees were known as human capital. Ramirez, Soto and Manzaneque (2020) recognized that human capital was the most significant asset in an organization supported from resourcebased view (RBV) theory. The most significant resource to the enhance the FP was IC under the concept of RBV, which was known as the knowledge resources owned by a firm, for instance, reputation, know-how and patents (Castro, Vial, \& Verde, 2019). HCE represented the index of value-added efficiency of human capital (Tran \& Vo, 2020). The experienced, 
brilliant and motivated human capital would able to increase the FP (Baig, Rehman, \& Latif, 2019). Ousama, Hammami and Abdulkarim (2020) stated that HCE plays a significant role in creating company value through differentiating its products and services and reducing the production costs.

$H_{7 A}$ : HCE of M-GLCs have a greater impact on ROA compared to that of $S$-GLCs.

$H_{7 B}$ : HCE of M-GLCs have a greater impact on Tobin's Q compared to that of S-GLCs.

$H_{7 C}: H C E$ of M-GLCs have a greater impact on EPS compared to that of S-GLCs.

\subsection{Relationship between Structural Capital Efficiency (SCE) and Firm Performance}

Structural capital covered the organization and infrastructure properties, for instance, database, system and process (Ting, et al. 2020). SCE was a proxy used to measure the valueadded efficiency of structural capital (Bayraktaroglu, et al. 2019). On the study of Ramirez, Soto and Manzaneque (2020), SCE represented the critical weapon for the firm in this knowledge age, because it generated the architecture and tools for shifting, establishing, continuing and strengthening knowledge throughout the firm operations. Prado, Severiche and Mendoza (2020) noted that the firm which was master and proficient in knowledge management practices would utilize their resources more creatively and efficiently. Most past studies noted that effective implementation of structural capital was significant to generate higher FP because the capabilities of a firm to offer customers with premium quality products and services will be subject to its productive investment in elements related to structural capital (Bayraktaroglu, et al. 2019).

$H_{8 A}$ : SCE of M-GLCs have a greater impact on ROA compared to that of S-GLCs.

$H_{8 B}$ : SCE of M-GLCs have a greater impact on Tobin's $Q$ compared to that of $S$-GLCs.

$H_{8 C}$ : SCE of M-GLCs have a greater impact on EPS compared to that of S-GLCs.

\subsection{Relationship between Capital Employed Efficiency (CEE) and Firm Performance}

Hsieh, Kiong and Asif (2020) defined the results of capital employed was the differences between total resources and intangible resources. According to Pratama, Innayah and Darmawan (2019), the efficient utilization of financial and physical capital was measured by CEE. In other words, CEE represented the efficiency of a firm to create value by utilizing its financial capital (Bayraktaroglu, et al. 2019). According to the findings of Oppong, Pattanayak and Irfan (2019), they found that CEE was significant and important in enhancing FP. Besides, Nimtrakoon (2015) argued that CEE and HCE were the most important drivers for market value and corporate performance. Results in the research of Ousama, Hammami and Abdulkarim (2020) showed an affirmative and significant relationship between CEE and FP.

$H_{9 A}$ : CEE of M-GLCs have a greater impact on ROA compared to that of S-GLCs.

$H_{9_{B}}$ : CEE of M-GLCs have a greater impact on Tobin's $Q$ compared to that of S-GLCs.

$H_{9 C}: C E E$ of $M-G L C s$ have a greater impact on EPS compared to that of S-GLCs.

\subsection{Control Variables}

Muslih, Sirait and Simanjuntak (2020) suggested that control variables (CV) are the variables that are not the main interest of this research. In order to avoid CV from interfering in the analysis of the impact of IVs on DVs, this research would cancel or neutralize it in the study. $\mathrm{CV}$ adopted in this research were firm size (FS) and Leverage (LV). According to Aslam, Ahmad and Amin (2018), the FS can be measured by the total assets of the company. Song, 
Lee and Kang (2021) stated that the larger FS were able to enjoy economies of scale and market power advantages, thus, it will be increased FP. Enache and Hussainey (2020) stated that LV could be measured by divided total liabilities with total assets of the firm. According to Rejeb and Missaoui (2019), the FP might be affected by the debt level because of the risk of default and costs of finance.

\subsection{Measurement of Firm Performance}

This paper proposed to use Return on Assets (ROA), Tobin's Q and Earnings per Share (EPS) for measuring FP. ROA was used as a corporate performance indicator when measured the capability of the company to generate earnings and returns for its shareholders (Zabri, Ahmad, \& Wah, 2016). Tobin's Q was adopted to evaluate FP because it can show the potential of the company to earn a future return (Ying \& Rayappan, 2020). EPS was a market-based indicator as it allowed comparing with existing studies and it can be utilised as a robustness check for the research findings (Kiplagat, 2020).

\section{Methodology}

The impact of CG variables and IC variables on FP of M-GLCs and S-GLCs were examined and compared. Data was extracted from 14 years' annual reports commencing from 2005 to 2018. Total sample size was 60 companies, which comprised of 34 M-GLCs and 26 S-GLCs. These GLCs were listed on Bursa Malaysia and Stock Exchange of Singapore respectively. Panel data analysis was adopted to examining the impact of CG and IC on FP for the two countries. Two categories of panel data analytic models used in this research study, which was the fixed-effect model and random effect model (Fitrianto \& Musakkal, 2016). The equation of dependent variables for panel data analysis was as follows:

$$
\begin{aligned}
& R O A_{i, t}=\beta_{0}+\beta_{1} F S_{i, t}+\beta_{2} L V_{i, t}+\beta_{3} B S_{i, t}+\beta_{4} I D_{i, t}+\beta_{5} B M_{i, t}+\beta_{6} W D_{i, t}+\beta_{7} A C_{i, t}+\beta_{8} C A_{i, t} \\
& +\beta_{9} H C E_{i, t}+\beta_{10} S C E_{i, t}+\beta_{11} C E E_{i, t} \\
& +\varepsilon_{i, t} \\
& +\beta_{8} C A_{i, t}+\beta_{9} H C E_{i, t}+\beta_{10} S C E_{i, t}+\beta_{11} C E E_{i, t} \\
& +\varepsilon_{i, t} \\
& E P S=\beta_{0}+\beta_{1} F S_{i, t}+\beta_{2} L V_{i, t}+\beta_{3} B S_{i, t}+\beta_{4} I D_{i, t}+\beta_{5} B M_{i, t}+\beta_{6} W D_{i, t}+\beta_{7} A C_{i, t}+\beta_{8} C A_{i, t} \\
& +\beta_{9} H C E_{i, t}+\beta_{10} S C E_{i, t}+\beta_{11} C E E_{i, t} \\
& +\varepsilon_{i, t}
\end{aligned}
$$

$\beta_{0}=$ Intercept for the regression model

$\beta_{1}, \beta_{2}, \beta_{3}, \beta_{4}, \beta_{5}, \beta_{6}, \beta_{7}, \beta_{8}, \beta_{9}, \beta_{10}, \beta_{11}=$ Partial regression coefficients

$i=$ Observation number in a cross - sectional data set

$t=$ Observation number in a time - series data set

$\varepsilon=$ Error terms of the regression model

\section{Results and Discussion}

Table 1. Hypothesis Testing Summary of ROA, Tobin's Q and EPS Results.

\begin{tabular}{|c|c|c|c|c|c|c|}
\hline \multirow{2}{*}{} & \multicolumn{2}{|c|}{ ROA } & \multicolumn{2}{c|}{ Tobin's Q } & \multicolumn{2}{c|}{ EPS } \\
\cline { 2 - 7 } & MY & SG & MY & SG & MY & SG \\
\cline { 2 - 7 } & $\mathbf{1 4}$ yrs & $\mathbf{1 4}$ yrs & $\mathbf{1 4}$ yrs & $\mathbf{1 4}$ yrs & $\mathbf{1 4}$ yrs & 14 yrs \\
\hline Constant & 0.731 & 0.051 & 0.353 & 0.158 & 0.748 & 0.450 \\
\hline FS & 0.100 & 0.750 & 0.200 & 0.119 & $\mathbf{+ 0 . 0 0 0}^{\text {*** }}$ & $\mathbf{+ 0 . 0 0 0}^{\text {**** }}$ \\
\hline
\end{tabular}




\begin{tabular}{|c|c|c|c|c|c|c|}
\hline $\mathbf{L V}$ & $-0.000^{* * * *}$ & $-0.000^{* * * *}$ & $+0.000^{* * * *}$ & $+0.000^{* * * *}$ & $-\mathbf{0 . 0 0 0} 0^{* * *}$ & 0.354 \\
\hline BS & 0.392 & $+0.000^{* * *}$ & 0.978 & $+0.039^{* *}$ & 0.687 & 0.183 \\
\hline ID & 0.210 & $+0.001^{* * * *}$ & 0.294 & 0.758 & 0.610 & $+0.056^{*}$ \\
\hline BM & 0.821 & 0.760 & $+0.037^{* *}$ & $+0.081^{*}$ & 0.323 & $-0.007^{* * *}$ \\
\hline WD & 0.929 & $-0.005^{* * *}$ & $+0.001^{* * *}$ & $+0.085^{*}$ & 0.981 & 0.239 \\
\hline IDAC & $+0.045^{\text {** }}$ & 0.864 & 0.312 & 0.100 & 0.940 & 0.902 \\
\hline CBCAC & 0.338 & 0.807 & 0.864 & 0.886 & $-0.000^{* * *}$ & 0.691 \\
\hline HCE & $+0.000^{* * * *}$ & $+0.002^{* * * *}$ & $+0.000^{* * * *}$ & 0.104 & $+0.000^{* * * *}$ & 0.220 \\
\hline SCE & 0.672 & $+0.001^{\text {**** }}$ & 0.805 & 0.698 & 0.343 & 0.434 \\
\hline CEE & $+0.000^{* * * *}$ & $+0.000^{* * *}$ & 0.664 & $+0.011^{* *}$ & $+0.002^{* * * *}$ & $-0.042^{* *}$ \\
\hline
\end{tabular}

$* * *$. Correlation is significant at the 0.01 level.

**. Correlation is significant at the 0.05 level.

*. Correlation is significant at the 0.1 level.

Table 2. Hausman Test.

\begin{tabular}{|c|c|c|c|c|}
\hline $\begin{array}{c}\text { Dependent } \\
\text { Variables }\end{array}$ & \multicolumn{2}{|c|}{ P-Value } & \multicolumn{2}{c|}{ Remarks* (Fixed Effect or Random Effect) } \\
\hline & MY & SG & MY & SG \\
\hline ROA & 0.000 & 0.002 & Fixed Effect Model & Fixed Effect Model \\
\hline Tobin's Q & 0.030 & 0.312 & Fixed Effect Model & Random Effect Model \\
\hline EPS & 0.015 & 0.027 & Fixed Effect Model & Fixed Effect Model \\
\hline
\end{tabular}

*Use Fixed Effect Model when P-Value $\leq 0.05$; Ramdom Effect Model when P-Value $>0.05$.

Table 3. Summary of Hypothesis Testing of M-GLCs and S-GLCs.

\begin{tabular}{|c|c|c|c|c|c|c|}
\hline IVs & $\begin{array}{c}\text { Research } \\
\text { Hypothesis }\end{array}$ & $\begin{array}{c}\text { Panel } \\
\text { Data } \\
\text { Analysis }\end{array}$ & $\begin{array}{c}\text { Research } \\
\text { Hypothesis }\end{array}$ & $\begin{array}{c}\text { Panel } \\
\text { Data } \\
\text { Analysis }\end{array}$ & $\begin{array}{c}\text { Research } \\
\text { Hypothesis }\end{array}$ & $\begin{array}{c}\text { Panel } \\
\text { Data } \\
\text { Analysis }\end{array}$ \\
\hline $\mathrm{BS}$ & $\mathrm{H}_{1 \mathrm{~A}}$ & $\mathrm{R}$ & $\mathrm{H}_{1 \mathrm{~B}}$ & $\mathrm{R}$ & $\mathrm{H}_{1 \mathrm{C}}$ & $\mathrm{I}$ \\
\hline $\mathrm{ID}$ & $\mathrm{H}_{2 \mathrm{~A}}$ & $\mathrm{R}$ & $\mathrm{H}_{2 \mathrm{~B}}$ & $\mathrm{I}$ & $\mathrm{H}_{2 \mathrm{C}}$ & $\mathrm{R}$ \\
\hline $\mathrm{BM}$ & $\mathrm{H}_{3 \mathrm{~A}}$ & $\mathrm{I}$ & $\mathrm{H}_{3 \mathrm{~B}}$ & $\mathrm{~A}$ & $\mathrm{H}_{3 \mathrm{C}}$ & $\mathrm{R}$ \\
\hline $\mathrm{WD}$ & $\mathrm{H}_{4 \mathrm{~A}}$ & $\mathrm{R}$ & $\mathrm{H}_{4 \mathrm{~B}}$ & $\mathrm{~A}$ & $\mathrm{H}_{4 \mathrm{C}}$ & $\mathrm{I}$ \\
\hline $\mathrm{IDAC}$ & $\mathrm{H}_{5 \mathrm{~A}}$ & $\mathrm{~A}$ & $\mathrm{H}_{5 \mathrm{~B}}$ & $\mathrm{I}$ & $\mathrm{H}_{5 \mathrm{C}}$ & $\mathrm{I}$ \\
\hline $\mathrm{CBCAC}$ & $\mathrm{H}_{6 \mathrm{~A}}$ & $\mathrm{I}$ & $\mathrm{H}_{6 \mathrm{~B}}$ & $\mathrm{I}$ & $\mathrm{H}_{6 \mathrm{C}}$ & $\mathrm{A}$ \\
\hline $\mathrm{HCE}$ & $\mathrm{H}_{7 \mathrm{~A}}$ & $\mathrm{~A}$ & $\mathrm{H}_{7 \mathrm{~B}}$ & $\mathrm{~A}$ & $\mathrm{H}_{7 \mathrm{C}}$ & $\mathrm{A}$ \\
\hline $\mathrm{SCE}$ & $\mathrm{H}_{8 \mathrm{~A}}$ & $\mathrm{R}$ & $\mathrm{H}_{8 \mathrm{~B}}$ & $\mathrm{I}$ & $\mathrm{H}_{8 \mathrm{C}}$ & $\mathrm{I}$ \\
\hline $\mathrm{CEE}$ & $\mathrm{H}_{9 \mathrm{~A}}$ & $\mathrm{I}$ & $\mathrm{H}_{9 \mathrm{~B}}$ & $\mathrm{R}$ & $\mathrm{H}_{9 \mathrm{C}}$ & $\mathrm{A}$ \\
\hline $\mathrm{A}$
\end{tabular}

$\mathrm{A}=$ Accept

$\mathrm{R}=$ Reject

$\mathrm{I}=$ Inconclusive

In Hypothesis 1 , results generated by the Panal Data rejected $\mathrm{H}_{1 \mathrm{~A}}$ and $\mathrm{H}_{1 \mathrm{~B}}$ while $\mathrm{H}_{1 \mathrm{C}}$ was inconclusive. This was consistent with the study of Abdulrasheed and Hamidu (2020), Rashid and Pervin (2019) and Vaidya (2019). From the analysis, it can be summarized that the BS of S-GLCs has greater impact on ROA and Tobin's Q when compared to M-GLCs. From Hypothesis 2, the analysis from Panel Data rejected $\mathrm{H}_{2 \mathrm{~A}}$ and $\mathrm{H}_{2 \mathrm{C}}$ while $\mathrm{H}_{2 \mathrm{~B}}$ was inconclusive. The findings were similar to the previous studies, such as Mustapha, Rashid and Bala (2020), Salleh, Lee and Joshi (2019) and Nwanne and Okonkwo (2019). The IDs of S-GLCs have greater impact on ROA and EPS compared to M-GLCs. In Hypothesis 3, results from Panel Data accepted $\mathrm{H}_{3 \mathrm{~B}}$ and did not accepted $\mathrm{H}_{3 \mathrm{C}}$, while $\mathrm{H}_{3 \mathrm{~A}}$ was inconclusive. The findings was identical with the study of Qudah, Azzam and Aleqab (2020), Mayur and Saravanan (2017) and Abdeljawad and Masri (2020). The BM of M-GLCs have greater impact on Tobin's Q 
compared to that of S-GLCs while the BM of S-GLCs have greater impact on EPS compared to M-GLCs. From Hypothesis $4, \mathrm{H}_{4 \mathrm{~B}}$ was accepted and $\mathrm{H}_{4 \mathrm{~A}}$ was rejected while $\mathrm{H}_{4 \mathrm{C}}$ was inconclusive based on the Panel Data Analysis. The findings were supported by the research of Mustapha, Rashid and Bala (2020), Rashid and Pervin (2019) and Abdeljawad and Masri (2020). In conclusion, the WD of M-GLCs showed greater impact on Tobin's Q compared to that of S-GLCs while the WD of S-GLCs have greater impact on ROA compared to MGLCs. Results of Hypothesis 5 from the Panel Data accepted $\mathrm{H}_{5 \mathrm{~A}}$ while $\mathrm{H}_{5 \mathrm{~B}}$ and $\mathrm{H}_{5 \mathrm{C}}$ were inconclusive. This was consistent with the research of Salleh, Lee and Joshi (2019), Farooque, Buachoom and Sun (2020) and Adhikary and Mitra (2016). In short, the IDAC of M-GLCs have greater impact on ROA compared to S-GLCs. In Hypothesis 6, results from the Panel Data accepted $\mathrm{H}_{6 \mathrm{C}}$ while $\mathrm{H}_{6 \mathrm{~A}}$ and $\mathrm{H}_{6 \mathrm{~B}}$ were inconclusive. In summary, the CBCAC of MGLCs have greater impact on EPS compared to S-GLCs. Outcomes of Hypothesis 7 from the Panel Data accepted $\mathrm{H}_{7 \mathrm{~A}}, \mathrm{H}_{7 \mathrm{~B}}$ and $\mathrm{H}_{7 \mathrm{C}}$. The results corresponded with the research of $\mathrm{Xu}$ and Li (2019), Ghasemi, Rostami and Mahdavirad (2019) and Nassar (2018). In conclusion, the HCE of M-GLCs have greater impact on ROA, Tobin's Q and EPS compared to S-GLCs. Results of Hypothesis 8 from the Panel Data rejected $\mathrm{H}_{8 \mathrm{~A}}$ while $\mathrm{H}_{8 \mathrm{~B}}$ and $\mathrm{H}_{8 \mathrm{C}}$ were inconclusive. The results were similar to the prior research, for instance, Buallay, Cummings and Hamdan (2019), Hamdan (2018) and of Ahmad and Ahmed (2016). In short, the SCE of S-GLCs have greater impact on ROA compared to M-GLCs. In Hypothesis 9, findings from the Panel Data accepted $\mathrm{H}_{9 \mathrm{C}}$ and rejected $\mathrm{H}_{9 \mathrm{~B}}$ while $\mathrm{H}_{9 \mathrm{~A}}$ was inconclusive. The findings was consistent with the past studies, such as Chowdhury, Rana and Azim (2019), Buallay, Cummings and Hamdan (2019) and Ahmad and Ahmed (2016). In short, the findings were unable to conclude CEE because of both M-GLCs and S-GLCs have the same significant impact on ROA; S-GLCs have greater impact on Tobin's Q compared to M-GLCs and MGLCs have greater impact on EPS compared to S-GLCs.

\section{Conclusion and Recommendations}

The objective of the study was to examine and determine the impact of CG variables and IC variables between M-GLCs' and S-GLCs' FP. A summary of conclusive notes was drawn. In general, the CG variables of S-GLCs have greater impact on FP compared to M-GLCs based on the number of significant variables, for instance, BS, ID, BM, and WD. M-GLCs should improve implementing appropriate CG recommendation in order to maximize shareholders' wealth. In addition, IC variables of M-GLCs revealed greater impact on FP than S-GLCs. It can be concluded that CG variables of S-GLCs have greater impact on FP compared to M-GLCs while the findings of the IC variables of M-GLCs have greater impact on FP compared to S-GLCs. Future research could conduct that collects secondary data from companies' annual reports and also gather primary data by distributing questionnaires. Further research can expand the sample size by involving the GLCs of other countries.

\section{References}

Abdeljawad, I., \& Masri, R. (2020). Board characteristics and corporate performance: Evidence from Palestine. An-Najah University Journal for Research, 34(3), 1-26. doi:10.2139/ssrn.3533334

Adhikary, B., \& Mitra, R. (2016). Determinants of audit committee independence in the financial sector of Bangladesh. Applied Finance and Accounting, 2(2), 46-56. doi:10.11114/afa.v2i2.1591

Ahmad, M., \& Ahmed, N. (2016). Testing the relationship between intellectual capital and a firm's performance: an empirical investigation regarding financial industries of 
Pakistan. International Journal of Learning and Intellectual Capital, 13(2), 250273.

Arulvel, K., \& Pratheepkanth, P. (2019). Board composition and firm performance: The Sri Lanka case. Arabian Journal of Business and Management Review (Oman Chapter), 8(1), 40-50. doi:10.12816/0052851

Astami, E., \& Rusmin, R. (2020). The role of board of directors and audit committee in financially distressed firms. International Journal of Service Management and Sustainability, 3(1), 113-144. doi:10.24191/ijsms.v3i1.8046

Baig, F., Rehman, I., \& Latif, F. (2019). What drives the impact of women directors on firm performance? Evidence from intellectual capital efficiency of US listed firms. Journal of Intellectual Capital, 1-18. doi:10.1108/JIC-09-2019-0222I

Barr, M. (2019). Chua Beng Huat liberalism disavowed: Communitarianism and state capitalism in Singapore. Journal Of Social Issues In Southeast Asia, 8(2), 338-341. doi:10.20495/seas.8.2_338

Bayraktaroglu, A., Calisir, F., \& Baskak, M. (2019). Intellectual capital and firm performance: an extended VAIC model. Journal of Intellectual Capital, 20(3), 406-425. doi:10.1108/JIC-12-2017-0184

Boateng, F., Manu, D., \& Adesi, M. (2019). Alinging strategic objectives to corporate governance objectives in construction professional service firms. Journal of Construction Project Management and Innovation, 9(1), 1-17.

Bually, A., Cummings, R., \& Hamdan, A. (2019). Intellectual capital efficiency and bank's performance: A comparative study after the global financial crisis. Pacific Accounting Review, 31(4), 672-694. doi:10.1108/PAR-04-2019-0039

Castro, G., Vial, I., \& Verde, M. (2019). Intellectual capital and the firm: evolution and research trends. Journal of Intellectual Capital, 20(4), 555-580. doi:10.1108/JIC12-2018-0221

Chen, C. (2016). Solving the puzzle of corporate governance of state-owned enterprises: The path of Temasek model in Singapore and lessons for China. Northwestern Journal of International Law and Business, 36(2), 303-370.

Chowdhury, L., Rana, T., \& Azim, M. (2019). Intellectual capital efficiency and organisational performance: In the context of the pharmaceutical industry in Bangladesh. Journal of Intellectual Capital, 20(6), 784-806. doi:10.1108/JIC-102018-0171

Dionne, G., Chun, O., \& Triki, T. (2019). The governance of risk management: The importance of directors' independence and financial knowledge. Risk Management and Insurance Review, 247-277. doi:10.1111/rmir.12129

Duppati, G., Rao, N., Matlani, N., \& Scrimgeour, T. (2020). Gender diversity and firm performance: evidence from India and Singapore. Applied Economics, 52(14), 1553-1565. doi:10.1080/00036846.2019.1676872

Einardottir, T., Rafndottir, G., \& Sigrun, M. (2020). Networks, homogeneity and gender in Icelandic business elites. Scandinavian Journal of Management, 36(1), 1-23. doi:10.1016/j.scaman.2019.101091

Enache, L., \& Hussainey, K. (2020). The substitutive relation between voluntary disclosure and corporate governance in their effects on firm performance. Review of Quantitative Finance and Accounting, 54, 413-445. doi:10.1007/s11156-01900794-8

Farooque, O., Buachoom, W., \& Sun, L. (2020). Board, audit committee, ownership and financial performance - emerging trends from Thailand. Pacific Accounting Review, 32(1), 54-81. doi:10.1108/PAR-10-2018-0079 
Fitrianto, A., \& Musakkal, N. (2016). Panel data analysis for Sabah construction industries: Choosing the best model. Procedia Economics and Finance, 35, 241-248. doi:10.1016/S2212-5671(16)00030-7

Ghasemi, A., Rostami, V., \& Mahdavirad, M. (2019). Intellectual capital, Tobin's Q ratio and stock return. UCT Journal of Management and Accounting Studies, 7(1), 1-7. doi:10.24200/jmas.vol7iss01pp1-7

Hamdan, A. (2018). Intellectual capital and firm performance: Differentiating between accounting-based and market-based performance. International Journal of Islamic and Middle Eastern Finance and Management, 11(1), 139-151. doi:10.1108/IMEFM-02-2017-0053

Haq, A., Zhao, B., \& Rehman, R. (2020). Corporate governance and firms performance: A case of India. SMART Journal of Business Management Studies, 16(1), 73-79. doi:10.1016/j.ibusrev.2018.08.004

Hsieh, C., Ting, I., \& Asif, J. (2020). The role of controlling shareholders in determining investments of intellectual capital among Taiwanese semiconductor companies. Journal of Intellectual Capital, 21(1), 62-86. doi:10.1108/JIC-05-2019-0091

Ibrahimy, A., \& Ramen, K. (2019). The impact of intellectual capital on firm performance in Malaysia. UNIMAS Review of Accounting and Finance, 2(1), 20-30. doi:10.33736/uraf.1996.2019

Ji, J., Talavera, O., \& Yin, S. (2020). Frequencies of board meetings on various topics and corporate governance: evidence from China. Review of Quantitative Finance and Accounting, 54, 69-110. doi:10.1007/s11156-018-00784-2

Kanojia, S., \& Khanna, G. (2019). Women directors on corporate boards: Evidence for good governance. Corporate Governance Insight, 1(1), 26-52.

Kao, M., Hodgkinson, L., \& Jaafar, A. (2019). Ownership structure, board of directors and firm performance: evidence from Taiwan. Corporate Governance, 19(1), 189-216. doi:10.1108/CG-04-2018-0144

Kiplagat, T. (2020). Does quality of corporate governance affect financial performance of listed firms in NSE, Kenya? African Journal of Education, Science and Technology, 5(4), 50-54. Retrieved from http://ajest.info/index.php/ajest/article/view/13

Kowalski, P., Buge, M., Sztajerowska, M., \& Egeland, M. (2013). State-qwned enterprises:Trade effects and policy implications. Paris: OECD.

Kweh, Q., Ahmad, N., \& Ting, I. (2019). Board gender diversity, board independence and firm performance in Malaysia. Institutions and Economies, 11(1), 1-20. Retrieved from https://ijie.um.edu.my/article/view/17017

Kweh, Q., Ting, I., \& Hanh, L. (2019). Intellectual capital, governmental presence, and firm performance of publicly listed companies in Malaysia. International Journal of Learning and Intellectual Capital, 16(2), 193-211. doi:10.1504/IJLIC.2019.098932

Larkin, M. (2020). Board gender diversity, corporate reputation and market performance. International Journal of Banking and Finance, 9(1), 1-26. Retrieved from http://ejournal.uum.edu.my/index.php/ijbf/article/view/8446

Masulins, R., \& Zhang, E. (2019). How valuable are independent directors? Evidence from external distractions. Journal of Financial Economics, 132(3), 226-256. doi:10.1016/j.jfineco.2018.02.014

Mayur, M., \& Saravanan, P. (2017). Performance implications of board size, composition and activity: empirical evidence from the Indian banking sector. Corporate Governance, 17(3), 466-489. doi:10.1108/CG-03-2016-0058

Merendino, A., \& Melville, R. (2019). The board of directors and firm performance: empirical evidence from listed companies. Corporate Governance, 19(3), 508-551. doi:10.1108/CG-06-2018-0211 
Mohamad, S., Pantamee, A., \& Keong, O. (2020). Corporate governance and firm performance: Evidence from listed Malaysian firms. International Journal of Psychosocial Rehabilitation, 24(2), 3668-3678. doi:10.37200/IJPR/V24I2/PR200690

Muslih, M., Sirait, D., \& Simanjuntak, D. (2020). The effect of financing decisions and investment decisions on the performance of property companies, real estate, \& building construction registered in Indonesia Stock Exchange moderated by corporate governance and risk management with firm size as control variable. South East Asia Journal of Contemporary Business, Economics and Law, 22(3), 137-149.

Mustapha, U., Rashid, N., \& Bala, H. (2020). Corporate governance and financial performance of Nigeria listed banks. Journal of Advanced Research in Dynamical and Control Systems, 12(1), 5-11. doi:10.5373/JARDCS/V12I1/20201002

Nassar, S. (2018). The impact of intellectual capital on firm performance of the Turkish real estate companies before and after the crisis. European Scientific Journal, 14(1), 2945. doi:10.19044/esj.2018.v14n1p29

Nimtrakoon, S. (2015). The relationship between intellectual capital, firms' market value and financial performance: Empirical evidence from the ASEAN. Journal of Intellectual Capital, 16(3), 587-618. doi:10.1108/JIC-09-2014-0104

Norzaiton, I., \& Hafizah, S. (2019). Audit committee and financially distressed firms in Malaysia. International Journal of Accounting, Finance and Business, 4(18), 92-107. Retrieved from http://www.ijafb.com/

Nwanne, T., \& Okonkwo, E. (2019). Corporate Board Characteristics and Deposit Money Banks (DMBs) Performance in Nigeria for the period 2008-2017. Archives of Business Research, 7(5), 75-95. doi:10.14738/abr.75.6531

Obermann, J., Velte, P., \& Gerwanski, J. (2020). Mutualistic symbiosis? Combining theories of agency and stewardship through behavioral characteristics. Management Research Review, 1-23. doi:10.1108/MRR-07-2019-0317

Oppong, G., Pattanayak, J., \& Irfan, M. (2019). Impact of intellectual capital on productivity of insurance companies in Ghana: A panel data analysis with System GMM estimation. Journal of Intellectual Capital, 20(6), 763-783. doi:10.1108/JIC-122018-0220

Ousama, A., Hammami, H., \& Abdulkarim, M. (2020). The association between intellectual capital and financial performance in the Islamic banking industry: An analysis of the GCC banks. International Journal of Islamic and Middle Eastern Finance and Management, 13(1), 75-93. doi:10.1108/IMEFM-05-2016-0073

Prado, A., Severiche, R., \& Mendoza, A. (2020). Conditions of knowledge management, innovation capability and firm performance in Colombian NTBFs: A measurement scale. VINE Journal of Information and Knowledge Management Systems, 1-16. doi:10.1108/VJIKMS-09-2019-0142

Pratama, B., Innayah, M., \& Darmawan, A. (2019). The effect of intellectual capital towards firm financail performance: Study in high-tech firms in Indonesia and Malaysia. International Proceeding ASEAN YOUTH CONFERENCE 2018, 685-691. doi:10.5281/zenodo.3191123

Puni, A., \& Anlesinya, A. (2020). Corporate governance mechanisms and firm performance in a developing country. International Journal of Law and Management, 1-23. doi:http://dx.doi.org/10.1108/IJLMA-03-2019-0076

Qudah, A., Azzam, M., \& Aleqab, M. (2020). The impact of board of directors characteristics on banks performance: Evidence from Jordan. Academy of Accounting and Financial Studies Journal, 23(2), 1-12. Retrieved from https://www.abacademies.org 
Ramirez, Y., Soto, J., \& Manzaneque, M. (2020). How does intellectual capital efficiency affect firm performance? The moderating role of family management. International Journal of Productivity and Performance Management, 1-28. doi:10.1108/IJPPM03-2019-0119

Rashid, M., \& Pervin, R. (2019). Board characteristics and firm performance: Evidence from listed banking institutions of Bangladesh. The Cost and Management, 47(1), 3-11.

Rejeb, J., \& Missaoui, I. (2019). Corporate governance and firm performance: The case of Tunisian. Journal of Business \& Financial Affairs, 8(1), 1-7. doi:10.4172/21670234.1000365

Rekha, H. (2019). Does gender diversity of boards affect performance? Evidence from Indian banking sector. IUP Journal of Bank Management, 18(2), 41-56.

Salleh, N., Lee, C., \& Joshi, P. (2019). Corporate governance, disclosure and firm performance: empirical findings from Malaysia. Afro-Asian Journal of Finance and Accounting, 9(3), 269-290. doi:10.1504/AAJFA.2019.100977

Shachi, C., Jophi, J., \& Prakash, M. (2020). Impact of intellectual capital on financial performance of banking and financial services sector: Comparative study. Studies in Indian Place Names, 40(40), 770-786.

Soei, C., Setiawan, A., \& Fitriani, K. (2019). Maturity level of good corporate governance (GCG) principles implementation: Case study from micro and small enterprises in Bandung. In G. Ade , W. Isma, \& U. Cep, Global competitiveness: Business transformation in the digital era (pp. 29-35). London : Taylor \& Francis Group.

Song, H., Lee, S., \& Kang, K. (2021). The influence of board interlocks on firm performance: In the context of geographic diversification in the restaurant industry. Tourism Management, 83, 1-8. doi:10.1016/j.tourman.2020.104238

Syajarul, I., \& Shifa, N. (2019). Board diversity and firm performance in the construction, manufacturing, and trading/services industries. Asian Journal of Accounting \& Governance, 12, 183-193. doi:10.17576/AJAG-2019-12-15

Tan, S., \& Patricia, R. (2020). Impact of corporate governance practices on firm performance in Malaysia. International Journal of Psychosocial Rehabilitation, 24(2), 909-916. doi:10.37200/IJPR/V24I2/PR200399

Ting, I., Ren, C., \& Chen, F. (2020). Interpreting the dynamic performance effect of intellectual capital through a value-added based perspective. Journal of Intellectual Capital, 1-21. doi:10.1108/JIC-05-2019-0098

Tran, N., \& Vo, D. (2020). Human capital efficiency and firm performance across sectors in an emerging market. Cogent Business \& Management, 7(1), 1-15. doi:10.1080/23311975.2020.1738832

Ullah, S., \& Kamal, Y. (2020). Corporate governance, political connections and firm performance: The role of political regimes and size. Global Business Review, 1-23. doi:10.1177/0972150919876520

Vaidya, P. (2019). Board size and firm performance: A study on BSE 100 companies. Journal of Management, 6(3), 117-123. Retrieved from http://www.iaeme.com/JOM/index.asp

Vitolla, F., Raimo, N., \& Rubino, M. (2020). Board characteristics and integrated reporting quality: an agency theory perspective. Corporate Social Responsibility and Environment Management, 27(2), 1152-1163. doi:10.1002/csr.1879

Wahid, A. (2019). The effects and the mechanisms of board gender diversity: Evidence from financial manipulation. Journal of Business Ethics, 159, 705-725. doi:10.1007/s10551-018-3785-6

Wang, Y., Abbasi, K., \& Babajide, B. (2020). Corporate governance mechanisms and firm performance: evidence from the emerging market following the revised CG code. Corporate Governance, 20(1), 158-174. doi:10.1108/CG-07-2018-0244 
Wijethilake, C., \& Ekanayake, A. (2019). CEO duality and firm performance: the moderating roles of CEO informal power and board involvements. Social Responsibility Journal, 1-22. doi:10.1108/SRJ-12-2018-0321

Xu, J., \& Li, J. (2019). The impact of intellectual capital on SMEs' performance in China. Journal of Intellectual Capital, 20(4), 488-509. doi:10.1108/JIC-04-2018-0074

Ying, T., \& Rayappan, P. (2020). Impact of corporate governance practices on firm performance in Malaysia. International Journal of Psychosocial Rehabilitation, 24(2), 909-916. doi:10.37200/IJPR/V24I2/PR200399

Younas, Z., Klein, C., \& Trabert, T. (2019). Board composition and corporate risk-taking: a review of listed firms from Germany and the USA. Journal of Applied Accounting Researc, 20(4), 526-542. doi:10.1108/JAAR-01-2018-0014

Zabri, S., Ahmad, K., \& Wah, K. (2016). Corporate governance practices and firm performance: Evidence from top 100 public listed companies in Malaysia. Procedia Economics and Finance, 35, 287-296. doi:10.1016/S2212-5671(16)00036-8 